\title{
Rootstock and Plastic Mulch Effect on Watermelon Flowering and Fruit Maturity in a Verticillium dahliae- Infested Field
}

\author{
Pinki Devi \\ Department of Horticulture, Washington State University, Northwestern \\ Washington Research and Extension Center, 16650 State Route 536, Mount \\ Vernon, WA 98273
}

Penelope Perkins-Veazie

Department of Horticultural Science, Plants for Human Health Institute, North Carolina State University, 600 Laureate Way, Kannapolis, NC 28081

Carol A. Miles

Department of Horticulture, Washington State University, Northwestern Washington Research and Extension Center, 16650 State Route 536, Mount Vernon, WA 98273

Additional index words. fruit quality, grafting, harvest time, scion, soilborne disease

Abstract. Separately, grafting and the use of plastic mulch can increase yield, quality, and early harvest of watermelon (Citrullus lanatus), especially when plants are under biotic and/ or abiotic stress. A 2-year field study was conducted to evaluate the combination of four different rootstocks and two types of plastic mulch (black and clear) on date of watermelon first flowering, fruit ripening, yield, and fruit quality when plants were exposed to Verticillium dahliae. Seedless watermelon cv. Secretariat was grafted onto rootstocks Lagenaria siceraria cv. Pelop, Benincasa hispida cv. Round, and two interspecific hybrid squash rootstocks Cucurbita maxima $\times C$. moschata cvs. Super Shintosa and Tetsukabuto, with nongrafted 'Secretariat' as the control. Fruit were harvested 0,7 , and 14 days after both the leaflet and tendril attached to the fruit pedicel were completely dry (fruit considered to be physiologically mature). The area under the disease progress curve (AUDPC) values for verticillium wilt were not different for mulch type in either year, although the overall AUDPC value was greatly reduced in the four grafted treatments (227) compared with nongrafted (743). There was no difference in days to male or female flowering due to mulch type or year, and rootstock did not affect first flowering of male flowers. Female flowering was 14 and 11 days later in 2018 and 2019, respectively, for 'Secretariat' grafted onto bottle gourd 'Round' compared with 'Secretariat' grafted onto 'Tetsukabuto'. Female flowering of 'Secretariat' on 'Round' was also 7 days later compared with nongrafted 'Secretariat' both years. However, days to first harvest was not different with mulch or rootstock and was 92 days after transplanting (DAT) in 2018 and 114 DAT in 2019. There was no difference in yield (fruit number and weight) due to year, harvest date, or mulch, but there was a difference due to grafting. 'Secretariat' grafted onto 'Super Shintosa' had the greatest total number and weight of fruit per plant $(3.7$ and $14.8 \mathrm{~kg}$, respectively), and nongrafted 'Secretariat' had the lowest ( 0.7 and $3.2 \mathrm{~kg}$, respectively). Fruit quality attributes hollow heart formation (rating 3.2/5 on average), hard seed count (6 on average), total soluble solids (11\% on average), and lycopene content were not different among mulch type, rootstock treatment, or harvest date; however, lycopene content did differ due to year (52.44 and $32.51 \mu \mathrm{g} \cdot \mathrm{g}^{-1}$ in 2018 and 2019, respectively). Flesh firmness was highest for watermelon grafted onto 'Super Shintosa' rootstock $(6.7 \mathrm{~N})$ and lowest for nongrafted watermelon $(4.3 \mathrm{~N})$. Overall, rootstocks reduced verticillium wilt severity and increased fruit yield whereas mulch had no effects, and $5 \mathrm{~V}$. dahliae colony forming units (cfu)/g of soil may be the minimum level for impact on watermelon fruit yield.

Watermelon (Citrullus lanatus) production is limited by verticillium wilt (caused by Verticillium dahliae) throughout Washington State, and in western Washington where watermelon are produced on a small scale for direct marketing, production is further limited by warm summer temperatures $\left(15^{\circ} \mathrm{C}\right.$ on average). In this environment, grafting watermelon onto disease-resistant rootstock can be an effective management approach for verticillium wilt (Buller et al., 2013; Dabirian et al., 2017; Wimer et al., 2015). Additionally, increasing soil temperature with plastic mulch may also increase watermelon yield (Dabirian et al., 2017).

Verticillium wilt is a soilborne disease favored by moist soil and a temperature range of 21 to $27{ }^{\circ} \mathrm{C}$ (Berlanger and Powelson,
2000). The pathogen can persist in the soil or plant debris for up to 14 years in the absence of a compatible host (Bhat and Subbarao, 1999; Bruton et al., 2007). Verticillium wilt is problematic in watermelon production as the plant tends to remain symptomless until flowering and fruiting. The hyphae colonize the root cortex then invade the xylem vessels, where they spread to the aboveground part of the plant and interfere with water and nutrient uptake and transport throughout the plant (Berlanger and Powelson, 2000; Fradin and Thomma, 2006; Vallad and Subbarao, 2008). Watermelon has no known genetic resistance against $V$. dahliae, and fumigation is only somewhat effective (Pscheidt and Ocamb, 2019); thus, alternative strategies are critically needed to achieve successful disease management. Grafting watermelon plants onto disease-resistant rootstocks offers an alternative strategy, but grower adoption is contingent on information regarding rootstock disease-resistance. The most commonly used rootstocks for watermelon grafting are Lagenaria siceraria (bottle gourd), Cucurbita moschata (winter squash or pumpkin), and $C$. moschata $\times C$. maxima (interspecific squash hybrid). Although watermelon grafted onto commercial cucurbit rootstocks have shown increased tolerance to verticillium wilt, no cucurbit rootstocks are known to be completely resistant to $V$. dahliae (Attavar et al., 2020; Davis et al., 2008; Paplomatas et al., 2000; Paroussi et al., 2007; Wimer et al., 2015). Yet verticillium wilt incidence was lower on grafted watermelon plants grown in artificially infested soil (Paroussi et al., 2007). Additionally, verticillium wilt severity of grafted watermelon plants was reduced in naturally infested field sites in western Washington where soil populations of $V$. dahliae were 18 to $28 \mathrm{cfu} / \mathrm{g}$ (Buller et al., 2013; Dabirian et al., 2017; Wimer et al., 2015). Increased scion health and growth was attributed to increased root mass and vigor of commercial cucurbit rootstocks and associated increased water and nutrient uptake despite pathogen infection (Davis et al., 2008; Lee, 1994; Sakata et al., 2007).

To take advantage of grafting, growers also need information regarding fruit maturity in response to rootstock-scion combination and environmental conditions. Modification of hormonal signaling in response to the rootstock-scion combination can influence time of flowering and harvest date of grafted watermelon plants (Aloni et al., 2010; Davis et al., 2008; Pulgar et al., 2000; Sakata et al., 2007; Satoh, 1996). Sakata et al. (2007) reported that watermelon grafted onto bottle gourd (Lagenaria siceraria) had early formation of female flowers. In contrast, another study reported a delay in flowering of up to 1 week with watermelon grafted on bottle gourd, resulting in an equal delay in fruit maturity (Davis et al., 2008). Delayed flowering was also observed for watermelon cv. Fujihikari grafted onto pumpkin (Cucurbita maxima), wax gourd (Benincasa hispida), and interspecific hybrid 
squash rootstocks (C. maxima $\times$ C. moschata) compared with nongrafted treatments in the greenhouse (Yamasaki et al., 1994). In regard to fruit quality, most studies have assumed concurrent ripening of fruit from grafted and nongrafted plants, and fruit have been harvested at the same time for all treatments. Hollow heart (placental detachment from the rest of the flesh) and hard seed formation are morphological abnormalities sometimes associated with grafted triploid watermelon and may reflect rootstock-scion incompatibility or adverse environmental conditions or cultural practices (Davis et al., 2008; Lee, 1994; Yamasaki et al., 1994). Increased flesh firmness has been shown in many studies (Bruton et al., 2009; Dabirian et al., 2017; Davis and Perkins-Veazie, 2005; Devi et al., 2020; Kyriacou and Soteriou, 2015; Paroussi et al., 2007), while no change has been reported by some (Alan et al., 2018; Buller et al., 2013; Karaca et al., 2012). Similarly, for lycopene content, grafted watermelon fruit showed increased content compared with nongrafted fruit in some studies (Davis et al., 2008; Proietti et al., 2008), while there was no difference in other studies (Bruton et al., 2009; Dabirian et al., 2017; Soteriou and Kyriacou, 2014; Wimer et al., 2015). Further, a decrease in lycopene content has been reported with certain rootstock-scion combinations involving $L$. siceraria and $C$. argyrosperma (Candir et al., 2013; Davis and Perkins-Veazie, 2005). For total soluble solids (TSS), rootstock-scion combination can affect results (Davis et al., 2008; Flores et al., 2010; Proietti et al., 2008). Most studies did not find a significant effect in TSS for grafted watermelon with bottle gourd rootstocks (Alan et al., 2007; Alexopoulos et al., 2007; Candir et al., 2013; Yetisir and Sari, 2003 ), however, $0.5 \%$ to $1.0 \%$ reduction in TSS was reported for grafted compared with nongrafted watermelon treatments in a few studies (Bruton et al., 2009; Davis and Perkins-Veazie, 2005; Kyriacou and Soteriou, 2015; Rouphael et al., 2010). Davis and Perkins-Veazie (2005) further reported that TSS was reduced only in the grafted diploid watermelon treatment. Miguel et al. (2004) and Dabirian et al. (2017) found no difference in TSS of fruit from triploid watermelon grafted onto hybrid $(C$. maxima $\times C$. moschata) rootstock compared with nongrafted controls. However, elucidating effects of grafting on fruit maturity is difficult

\footnotetext{
Received for publication 19 May 2020. Accepted for publication 19 June 2020.

Published online 30 July 2020.

Funding support was provided by the U.S. Department of Agriculture National Institute of Food and Agriculture (NIFA) Specialty Crop Research Initiative Grant 2011-51181-30963 and NIFA Hatch project 1017286 . Technical assistance was provided by Patricia Kreider and Edward Scheenstra.

C.A.M. is the corresponding author. E-mail: milesc@ wsu.edu.

This is an open access article distributed under the CC BY-NC-ND license (https://creativecommons.org/ licenses/by-nc-nd/4.0/).
}

because senescence of leaflet and tendril attached to the fruit pedicel, skin color development, and ground spot formation have not been reported.

Black plastic mulch is commonly used in the production of many vegetable crops including watermelon, to conserve soil moisture, prevent weed emergence, promote early ripening, and prevent fruit rots (Baker et al., 1998; Brown and Channell-Butcher, 1999; Ibarra-Jimenez et al., 2005). Plastic mulch warms the soil, which enhances watermelon growth and yield in areas with a warm growing season (Parmar et al., 2013; Rao et al., 2017). For example, at Mount Vernon, WA, black plastic mulch increased soil temperature by $1.8{ }^{\circ} \mathrm{C}$ at a $10-\mathrm{cm}$ depth and doubled the yield of pie pumpkin compared with nonmulched soil (Ghimire et al., 2018). At the same location, Sintim et al. (2019) reported that soil temperature was 1 to $5{ }^{\circ} \mathrm{C}$ greater in black plastic mulch treatments compared with a no-mulch treatment early in the growing season, when the plant canopy had not fully developed. Later in the growing season, once the canopy had fully developed and the mulches were shaded, there was no difference in soil temperature. Clear plastic mulch has been shown to increase soil temperature by 2 to $3{ }^{\circ} \mathrm{C}$ compared with black plastic mulch in northwest Washington, especially early in the season before the crop canopy covers the mulch (Ghimire et al., 2020; Zhang et al., 2020). Dabirian et al. (2017) similarly found a higher soil temperature with clear compared with black plastic mulch treatments ( 30 vs. $25^{\circ} \mathrm{C}$, respectively) in Mount Vernon, WA, but there was no difference in watermelon yield between the treatments.

Watermelon is a high-value crop that is well suited for direct markets that are common in western Washington. In the northwestern United States, $V$. dahliae is present in many fields, and soil temperatures are relatively cool during the summer production season ( 18 to $20^{\circ} \mathrm{C}$ at $10-\mathrm{cm}$ depth) (Dabirian et al., 2017; Wimer et al., 2015). In this study, grafting in combination with plastic mulch was assessed for its effects on earlier watermelon fruit production, yield, and fruit quality under conditions of verticillium wilt.

\section{Materials and Methods}

Experimental location and design. This study was carried out in the same field in 2018 and 2019 at Washington State University Northwestern Washington Research and Extension Center (WSU NWREC), Mount Vernon, WA (lat. $48^{\circ} 43^{\prime} 24^{\prime \prime} \mathrm{N}$, long. $\left.122^{\circ} 39^{\prime} 09^{\prime \prime} \mathrm{W}\right)$. The region has a warm Mediterranean climate (Peel et al., 2007), and during the summer growing season (June through September), average temperature is $15^{\circ} \mathrm{C}$, precipitation is $170 \mathrm{~mm}$, and relative humidity (RH) is $80 \%$ (20-year average; AgWeatherNet, 2020). The soil type is Skagit silt loam (superactive, nonacid, mesic Fluvaquentic Endoaquepts) (U.S. Department of Agriculture Natural Resources Conservation
Service, 2019), and the field site was certified organic.

The experiment had a split-plot design with three replications of two main plot treatments and five subplot treatments, with 15 plants per subplot in both years. The main plot treatment was mulch (black and clear plastic, both $25.4 \mu \mathrm{m}$; Climagro, Delhi, ON, Canada), And the subplot treatment was grafting. Seedless watermelon cv. Secretariat (Sakata Seeds America, Inc., Morgan Hill, CA) was grafted onto four types of commercially available rootstocks: Lagenaria siceraria cv. Pelop (Rijk Zwaan, Salinas, CA), Benincasa hispida cv. Round (Kitazawa seed co., Oakland, CA), and two interspecific hybrid squash $(C$. maxima $\times C$. moschata $)$, cv. Super Shintosa (Syngenta Seeds, Minneapolis, MN), and Tetsukubato (American Takii, Salinas, CA). Nongrafted 'Secretariat' was the control. Beds were $3 \mathrm{~m}$ center to center, and spacing was $0.9 \mathrm{~m}$ between plants in a single row. The study included a border row on each side both years, plus border plants at the ends of all experiment rows.

Plant and field preparation. All plants were grown at WSU Mount Vernon NWREC, and grafting was with the one-cotyledon method following procedures developed for this site (Devi et al., 2020; Miles et al., 2016). Both years, the field was fertilized with 105 $\mathrm{kg} \cdot \mathrm{ha}^{-1}$ of nitrogen, $30 \mathrm{~kg} \cdot \mathrm{ha}^{-1}$ of phosphorus, and $70 \mathrm{~kg} \cdot \mathrm{ha}^{-1}$ of potassium (NutriRich $8 \mathrm{~N}-$ 0.8P-3.3K; Stutzman Environmental Products, Canby, OR). In 2018, supplemental sulfur was applied in the form of sulfate (12\% sulfur, Garden Pearls Gypsum; Columbia River Carbonates, Woodland, WA) at the rate of $20 \mathrm{~kg} \cdot \mathrm{ha}^{-1}$ based on soil test recommendations. Both years, fertilizer was applied using a drop spreader over bed centers, then beds were shaped (Rain-Flo 2600; Rain-Flo Irrigation, East Earl, PA), and drip tape (TTape model 508-08-340, 20-cm emitter spacing, 4.3 L. $\mathrm{min}^{-1}$ per $100 \mathrm{~m}$; Rivulis San Diego, CA) was simultaneously laid on the center of each bed and covered with plastic mulch. Beds were $15 \mathrm{~cm}$ tall and $90 \mathrm{~cm}$ wide. In 2018, all plants were transplanted to the field site on 11 June, and in 2019, transplanting was done on 21 May. Pollenizer 'Wild Card Plus' (Sakata Seeds America, Inc., Morgan Hill, CA) was planted at every third plant on the opposite side of each row both years.

Soil assays for $V$. dahliae. Soil samples were collected using a systematic sampling method in an X pattern before transplanting to estimate $V$. dahliae soil population. Samples were collected on 8 May 2018 and 23 Apr. 2019, and also at the end of the growing season on 11 Nov. 2018 and 24 Oct. 2019. At each sampling time, six soil cores, each measuring $4.5 \mathrm{~cm}$ diameter and $15 \mathrm{~cm}$ deep, were collected. Each soil core was broken into pieces and placed in a paper tray and allowed to air dry in a greenhouse for 1 week. From each of the six dried soil samples, a 1.5g subsample was placed in a sterile mortar and ground by firmly rotating a sterile pestle in a full circle 10 times, and $1 \mathrm{~g}$ was transferred to a salt shaker. To avoid cross 
contamination, mortars, pestles, and salt shakers were sterilized with $70 \%$ ethanol between the processing of samples. Each subsample then was carefully dispersed uniformly over 10 plates of Sorensen's NP-10 agar medium (Goud and Termorshuizen, 2003) following the method of Butterfield and DeVay (1977). The plates were then incubated in the dark at ambient temperature $\left(\approx 25{ }^{\circ} \mathrm{C}\right)$ for 4 weeks. The surface of the plates was rinsed under running tap water, and the number of cfu per gram of dry soil was estimated using a dissecting microscope at $40 \times$ magnification. The colonies of $V$. dahliae were identified by their morphology as described by Goud et al. (2003).

\section{Data Collection}

Environmental conditions. Meteorological data were collected throughout the growing season (May through September) by the WSU AgWeatherNet system located $0.5 \mathrm{~km}$ from the field site. Mean, minimum, and maximum temperatures; average $\mathrm{RH}$; total solar radiation; and total precipitation were recorded daily during the growing season each year. Soil temperature and volumetric water content were measured every $30 \mathrm{~min}$ using data loggers (Hobo Onset, Bourne, $\mathrm{MA})$. Temperature and moisture probes (S-TMB-M002 and S-SMC-M005 respectively; Onset Computer, Corp., Bourne, MA) were placed in the center of both main plots in the second replicate, at $10 \mathrm{~cm}$ depth under the plastic mulch and centered between two plants in the center of the bed.

Verticillium assessments. Plants were visually observed for characteristic symptoms of verticillium wilt (chlorosis, necrosis, and wilting) both years, and a severity rating was recorded for all plants in each subplot every week from the onset of foliar symptoms. Ratings occurred 58, 65, 72, 79, and 85 DAT, with the first rating on 8 Aug. and the last rating on 4 Sept. in both years. Percent severity was recorded on a per plant basis and the average per plot was calculated on each measurement date. At the end of the field study each year, AUDPC values were calculated from the severity ratings for each treatment to compare disease development among the treatments (Shaner and Finney, 1977) using the formula:

$$
\text { AUDPC }=\sum_{i=1}^{n}\left[\frac{Y_{i+n 1}+Y_{i}}{2}\right]\left[X_{i+1}-X_{i}\right]
$$

in which, $Y_{i}=$ disease severity (per unit) at the $\mathrm{i}^{\text {th }}$ observation, $X_{i}=$ time (days) at the $\mathrm{i}^{\text {th }}$ observation, and $n=$ total number of observations.

Flowering and harvest date. The emergence of the first fully open male and female flower on each plant in each plot was monitored between 9:00 AM and 11:00 AM 3 d per week (Monday, Wednesday, and Friday) both years. The first flower date was recorded for each plant, and the average was calculated for each plot. Fruit maturity was monitored in each plot $3 \mathrm{~d}$ per week (Monday, Wednesday, and Friday) for several weeks leading up to first harvest. Each fruit was tagged, and the date recorded when both the leaflet and tendril attached to the fruit pedicel were completely dry (fruit considered to be physiologically mature) (Georgia Vegetable Team, 2000). At least three fruit were harvested per plot for each maturity date: 0,7 , and $14 \mathrm{~d}$ after the leaflet and tendril were dry.

Fruit yield and quality. For each harvest date both years, the number and weight of harvested fruit were recorded for each plant per plot and total yield was calculated for each treatment. Three representative fruit per plot were randomly selected at each harvest date to assess fruit internal ripeness characteristics (fruit quality). Each fruit was cut in half longitudinally, and each half was rated for hollow heart based on a 0 to 5 scale, where $0=$ no visible cracking, marketable; $1=$ $<6 \mathrm{~mm}$ cracking in one direction, marketable; $2=6$ to $13 \mathrm{~mm}$ cracking in a single or multiple directions, marketable; $3=13$ to $25 \mathrm{~mm}$ cracking in one or multiple directions, not marketable; $4=25$ to $38 \mathrm{~mm}$ cracking in multiple directions, not marketable; and $5=$ $>38 \mathrm{~mm}$ cracking with center cavity of fruit exposed, not marketable. Each fruit was then quartered, and the number of black hard seeds were counted for the exposed fruit surfaces in all four quarters of each fruit. From one quarter, a $25-\mathrm{cm}^{3}$ sample was taken from the center and flesh firmness (reported as Newton, N) was measured to a depth of $1 \mathrm{~cm}$ with a penetrometer (FR-5120, range of the gauge 0.05-196.10 N; QA Supplies LLC, Norfolk, VA) equipped with a 4-mm diameter cylindrical blunt-end tip mounted on a drill-press. Juice from the sample was squeezed onto a digital refractometer (MISCO, Cleveland, $\mathrm{OH})$ to determine total soluble solids content ( $\%$ measured as ${ }^{\circ}$ Brix).

For lycopene analysis, $50 \mathrm{~cm}^{3}$ was removed from the center of each fruit, and held in plastic bags at $-20{ }^{\circ} \mathrm{C}$ until used for the measurement. Total lycopene was measured in 2018 from frozen samples at the Plants for Human Health Institute, North Carolina State University, Kannapolis, NC, following the method of Davis et al. (2003). Frozen samples were shipped overnight with dry ice. Samples were thawed, placed in a vial and ground using a cell and tissue homogenizer (Geno/Grinder; Spex SamplePrep, Metuchen, NJ). Five grams of the ground puree was diluted with $15 \mathrm{~mL}$ of distilled water (wt/ vol), and tubes were vortexed for $1 \mathrm{~min}$. The mixture was then placed in a $20-\mathrm{mL}$ glass cuvette and the absorbance (A) recorded at 560 and $700 \mathrm{~nm}$ using a colorimeter (UltraScan PRO Spectrophotometer; Hunter Associate Laboratory Inc., Reston, VA). Total lycopene was calculated using the following formula:

$$
\begin{aligned}
& \text { Total lycopene }\left(\mu \mathrm{g} \cdot \mathrm{g}^{-1}\right) \\
& =(\mathrm{A} 560-\mathrm{A} 700) 28 \times 4,
\end{aligned}
$$

where A560 represents the lycopene peak, A700 represents light scatter, 4 is the dilution factor, and 28 is the slope.
In 2019, total lycopene content was determined by spectrophotometer at WSU NWREC following the method of Buller et al. (2013), modified from Nagata and Yamashita (1992). In the modified method, 2:3 acetone:hexane solution was prepared $1 \mathrm{~d}$ before the analysis and kept in the refrigerator $\left(4^{\circ} \mathrm{C}\right)$, whereas in the original procedure, the solution was used immediately. The tubes were covered using aluminium foil in the modified procedure, whereas in the original method, tubes were not covered. After adding cold acetone:hexane solution to watermelon samples on the day of analysis in the modified procedure, the tubes were kept in the freezer $\left(-20{ }^{\circ} \mathrm{C}\right)$ for $1 \mathrm{~h}$, whereas in the original method, the analysis was done immediately. The following is a summary of the method used in the current study. Samples were removed from the freezer and kept at room temperature $\left(23^{\circ} \mathrm{C}\right)$ for $10 \mathrm{~min}$, then homogenized in a blender (Magic Bullet; Homeland Housewares, Pacoima, CA). Three 1-g puree subsamples were placed in separate plastic centrifuge tubes wrapped in aluminium foil, and $16 \mathrm{~mL}$ of a cold high-performance liquid chromatography grade 2:3 acetone:hexane solution was added to each tube. The tubes were agitated by hand for $1 \mathrm{~min}$ for thorough mixing, then returned back to the freezer at $-20{ }^{\circ} \mathrm{C}$ for $1.5 \mathrm{~h}$. Tubes were removed from the freezer and left to rest for $5 \mathrm{~min}$ to separate the hexane layer from the rest of the mixture. Three $\mathrm{mL}$ of the hexane layer was placed in a glass cuvette and absorbance determined with a spectrophotometer (ultraviolet-VIS spectrophotometer ultraviolet-1280; Shimadzu Scientific Instruments, Inc., Columbia, MD). Absorbance at 453, 505, 645, and $663 \mathrm{~nm}$ was recorded and total lycopene was calculated using the following formula:

$$
\begin{aligned}
\text { Lycopene }(\mu \mathrm{g} / \mathrm{g} \text { FW sample }) & \\
= & {[(-0.0458 \times \mathrm{A} 663)+(0.204 \times \mathrm{A} 645)} \\
& +(0.372 \times \mathrm{A} 505)-(0.0806 \times \mathrm{A} 453)] \\
& \times[10 / 0.1042],
\end{aligned}
$$

where $10 / 0.1042$ is the extinction coefficient for lycopene in hexane [adapted for $\mu \mathrm{g} / \mathrm{g}$ sample fresh weight $(\mathrm{FW})$; in the original method the formula was for $\mathrm{mg} / 100 \mathrm{~mL}$ of extract].

Statistical analysis. All data were analyzed using JMP software (Version 14.0.0 for Windows; SAS Institute, Cary, NC). The main plot and subplot treatments were explanatory variables, and flowering, fruit yield, fruit quality, and verticillium wilt severity were response variables. Data for all parameters were tested for normality using Shapiro-Wilk test and analyzed using analysis of variance. When significant effects were detected, means were discriminated using Tukey's honestly significant difference at significance level $P<0.05$. AUDPC values in 2018 and 2019 did not satisfy normality assumptions and were analyzed using nonparametric Wilcoxon test.

\section{Results}

Environmental and soil conditions. Environmental conditions were similar both years. 
The average air temperature was $16{ }^{\circ} \mathrm{C}$ during the 2018 growing season (June through September) and $15^{\circ} \mathrm{C}$ during the 2019 growing season (May through September) (Table 1). Average minimum temperature

was $10.5^{\circ} \mathrm{C}$, and average maximum temperature was $21.5^{\circ} \mathrm{C}$ for the 2 years. Average daily RH was $75 \%$ in 2018 and 64\% in 2019. Although total precipitation was $78 \mathrm{~mm}$ in 2018 and $234 \mathrm{~mm}$ in $2019,140 \mathrm{~mm}$ of

Table 1. Environmental and soil conditions during the growing season at Mount Vernon, WA, in 2018 and 2019.

\begin{tabular}{|c|c|c|c|c|}
\hline$\overline{\text { Environmental parameters }^{2}}$ & \multicolumn{2}{|c|}{$2018^{y}$} & \multicolumn{2}{|c|}{2019} \\
\hline Average daily air temperature $\left({ }^{\circ} \mathrm{C}\right)$ & \multicolumn{2}{|c|}{16} & \multicolumn{2}{|c|}{15} \\
\hline Average daily max air temperature $\left({ }^{\circ} \mathrm{C}\right)$ & \multicolumn{2}{|c|}{22} & \multicolumn{2}{|c|}{21} \\
\hline Average daily min air temperature $\left({ }^{\circ} \mathrm{C}\right)$ & \multicolumn{2}{|c|}{10} & \multicolumn{2}{|c|}{11} \\
\hline Total solar radiation $\left(\mathrm{MJ} \cdot \mathrm{m}^{-2}\right)$ & \multicolumn{2}{|c|}{2207} & \multicolumn{2}{|c|}{2018} \\
\hline Relative humidity $(\%)$ & \multicolumn{2}{|c|}{75} & \multicolumn{2}{|c|}{64} \\
\hline Total rainfall (mm) & \multicolumn{2}{|c|}{78} & \multicolumn{2}{|c|}{$234^{\mathrm{x}}$} \\
\hline \multirow[t]{2}{*}{ Wind speed (kph) } & \multicolumn{2}{|c|}{5.3} & \multicolumn{2}{|c|}{5.4} \\
\hline & Black $^{w}$ & Clear & Black & Clear \\
\hline Soil temperature $\left({ }^{\circ} \mathrm{C}\right)^{v}$ & 28 & 31 & 23 & 25 \\
\hline Volumetric water content $\left(\mathrm{cm}^{3} \cdot \mathrm{cm}^{3}\right)^{\mathrm{v}}$ & 0.22 & 0.19 & 0.25 & 0.23 \\
\hline
\end{tabular}

${ }^{\mathrm{z}}$ Data from Washington State University Ag WeatherNet Station located $\approx 0.5 \mathrm{~km}$ from the field site.

${ }^{y_{2}} 2018$ growing season was 11 June to 11 Sept. 2019 growing season was 21 May to 12 Sept.

${ }^{\mathrm{x}}$ On 9 Sept. 2019 there was $140 \mathrm{~mm}$ of rainfall, $3 \mathrm{~d}$ before harvest.

${ }^{\text {w}}$ Black and clear plastic mulch both years was $25.4 \mu \mathrm{m}$ (Climagro, Delhi, ON, Canada).

${ }^{\mathrm{v}}$ Measured every $30 \mathrm{~min}$ at $10 \mathrm{~cm}$ depth with data loggers (Hobo Onset, Bourne, MA) and averaged for the growing season.

Table 2. Area under the disease progress curve (AUDPC) values for severity of verticillium wilt in 2018 and 2019, and days after transplanting (DAT) for appearance of first male and female flower (years combined) of watermelon grown with black and clear plastic mulch (grafted and nongrafted combined) and for grafting treatments at Mount Vernon, WA.

\begin{tabular}{|c|c|c|c|c|}
\hline \multirow[b]{2}{*}{ Treatment $^{2}$} & \multicolumn{2}{|c|}{ AUDPC value ${ }^{y}$} & \multicolumn{2}{|c|}{ First flowering (DAT) } \\
\hline & 2018 & 2019 & Male & Female \\
\hline Black mulch & 445 & 467 & 60 & 55 \\
\hline Clear mulch & 345 & 387 & 59 & 55 \\
\hline$P$ value & 0.15 & 0.09 & 0.80 & 1.00 \\
\hline Secretariat (control) & $683 \mathrm{a}^{\mathrm{x}}$ & $802 \mathrm{a}$ & 59 & $54 \mathrm{bc}$ \\
\hline $\mathrm{S} /$ Tetsukabuto & $183 \mathrm{~b}$ & $202 \mathrm{~b}$ & 58 & $49 \mathrm{c}$ \\
\hline S/Super Shintosa & $187 \mathrm{~b}$ & $220 \mathrm{~b}$ & 56 & $56 \mathrm{~b}$ \\
\hline S/Pelop & $198 \mathrm{~b}$ & $200 \mathrm{~b}$ & 57 & $55 \mathrm{abc}$ \\
\hline S/Round & $298 \mathrm{~b}$ & $323 \mathrm{~b}$ & 60 & $61 \mathrm{a}$ \\
\hline$P$ value & $<0.0001$ & $<0.0001$ & 0.60 & 0.02 \\
\hline
\end{tabular}

${ }^{\mathrm{z}}$ Black and clear plastic mulch both years was $25.4 \mu \mathrm{m}$ (Climagro, Delhi, ON, Canada). All grafted plants had watermelon cv. Secretariat (S) as the scion and are denoted as scion/rootstock.

${ }^{\mathrm{y}}$ Disease severity was recorded as the percent of the plot canopy displaying verticillium wilt visual symptoms (chlorosis, necrosis, and wilting); each year AUDPC values were calculated based on four rating dates, from the onset of disease symptoms and each week thereafter.

${ }^{\mathrm{x}}$ Means with the same letter within a column are not significantly different at $P<0.05$; means were discriminated using Tukey's honestly significant difference. rainfall fell on 9 Sept. 2019, 3 d before harvest. Total solar radiation was 2207 $\mathrm{MJ} \cdot \mathrm{m}^{-2}$ in 2018 and $2018 \mathrm{MJ} \cdot \mathrm{m}^{-2}$ in 2019. Average soil temperature at $10-\mathrm{cm}$ depth under black plastic mulch was $25^{\circ} \mathrm{C}$, which was $3{ }^{\circ} \mathrm{C}$ lower than under clear plastic mulch $\left(28{ }^{\circ} \mathrm{C}\right)$, and both were 7 to $10^{\circ} \mathrm{C}$ greater than the 2-year average bare ground soil temperature $\left(18.5{ }^{\circ} \mathrm{C}\right)$. Average soil moisture under clear plastic mulch $(0.21$ $\mathrm{cm}^{3} \cdot \mathrm{cm}^{3}$ ) was slightly lower throughout the growing season than under black plastic mulch $\left(0.24 \mathrm{~cm}^{3} \cdot \mathrm{cm}^{3}\right)$ (Table 1).

Verticillium assessments. In 2018, V. dahliae soil population density was $5 \mathrm{cfu} / \mathrm{g}$ at transplanting and $10 \mathrm{cfu} / \mathrm{g}$ after harvest. In 2019 , the soil population of $V$. dahliae was 15 $\mathrm{cfu} / \mathrm{g}$ at the time of transplanting and $21 \mathrm{cfu} / \mathrm{g}$ after harvest. There was no significant difference in AUDPC value due to mulch treatment either year $(P=0.15$ and $P=$ 0.09 , respectively) (Table 2 ). In both years, the overall AUDPC value for verticillium wilt was more than 3 times greater for nongrafted 'Secretariat' watermelon (683 and 802 in 2018 and 2019, respectively) than for the four grafted treatments (on average 217 and 236 in 2018 and 2019, respectively) $(P<0.0001$ both years $)$ (Table 2). There was also no interaction between mulch treatment and grafting $(P=$ $0.66)$, nor between year, mulch, and grafting treatment $(P=0.78)$ (Table 3$)$.

Flowering and harvest date. Male flowers first appeared 58 DAT on average for all treatments in both 2018 and 2019, and was not different for mulch $(P=0.30)$, grafting treatment $(P=0.80)$, or year $(P=0.64)$ (Table 2). Appearance of first female flower was unaffected by mulch treatment $(P=1.00)$ or year $(P=0.80)$. Grafting treatment did affect female flowering $(P=0.02)$, and on average was earliest for 'Secretariat' grafted onto 'Tetsukabuto' (49 DAT), followed by 'Super Shintosa', 'Pelop', and nongrafted (55 DAT), and latest for 'Secretariat' grafted to 'Round' (61 DAT) (Table 2). There were no interactions among mulch, grafting, and year for male or female flowering (Table 3).

Table 3. Interactions ( $P$ values) from analysis of variance of the main factors "mulch," "grafting," "day of harvest," and "year" for the parameters measured for grafted and nongrafted watermelon in 2018 and 2019.

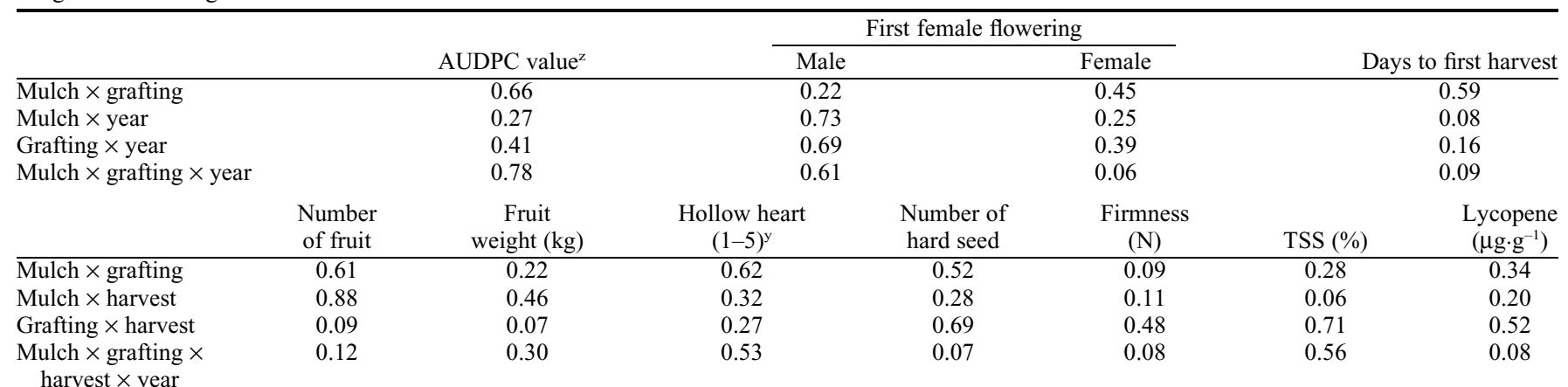

${ }^{\mathrm{z}}$ Disease severity was recorded as the percent of the plot canopy displaying verticillium wilt visual symptoms (chlorosis, necrosis, and wilting); each year area under the disease progress curve (AUDPC) values were calculated based on four rating dates, from the onset of disease symptoms and each week thereafter.

${ }^{\mathrm{y}}$ Hollow heart rating on a 0 to 5 scale, where $0=$ no visible cracking; $1=<6 \mathrm{~mm}$ cracking in one direction, marketable; $2=6$ to $13 \mathrm{~mm}$ cracking in a single or multiple directions, marketable; $3=13$ to $25 \mathrm{~mm}$ cracking in one or multiple directions, not marketable; $4=25$ to $38 \mathrm{~mm}$ cracking in multiple directions, not marketable; and $5=>38 \mathrm{~mm}$ cracking with center cavity of fruit exposed, not marketable. 
Days to first harvest $(0 \mathrm{~d})$, when both the leaflet and tendril attached to the fruit pedicel were completely dry, was on 11 Sept. 2018 (92 DAT) and 12 Sept. 2019 (114 DAT), and did not differ due to mulch or grafting treatments $(P=0.78$ and $P=0.45$, respectively). There were no interactions among year, mulch, and grafting (Table 3). Second harvest (7 d) was at 99 DAT in 2018 and 121 DAT in 2019, and third harvest (14 d) was at 106 DAT in 2018 and 128 DAT in 2019.

Fruit yield and quality. There were no differences in average number of fruit and

Table 4. Average watermelon fruit number and weight (kilograms) per plant for watermelon cv. Secretariat combined for nongrafted and grafted (rootstock cvs. Tetsukabuto, Super Shintosa, Pelop, and Round) treatments, at three harvest dates $(0,7$, and $14 \mathrm{~d}$ after physiological maturity; both the leaflet and tendril attached to the fruit pedicel were completely dry) and two plastic mulch types (black and clear) at Mount Vernon, WA, in 2018 and 2019.

\begin{tabular}{|c|c|c|c|c|}
\hline \multirow[b]{2}{*}{ Treatment } & \multicolumn{2}{|c|}{ Number of fruit } & \multicolumn{2}{|c|}{ Fruit wt (kg) } \\
\hline & 2018 & 2019 & 2018 & 2019 \\
\hline$\overline{0 \mathrm{~d}}$ & 2.2 & 1.8 & 11.3 & 9.1 \\
\hline $7 \mathrm{~d}$ & 2.1 & 1.8 & 12.2 & 11.7 \\
\hline $14 \mathrm{~d}$ & 1.9 & 2.4 & 10.5 & 7.4 \\
\hline$P$ value & 0.32 & 0.25 & 0.56 & 0.24 \\
\hline Black $^{z}$ & 2.3 & 2.1 & 11.4 & 10.3 \\
\hline Clear & 2.2 & 1.9 & 10.6 & 8.5 \\
\hline$P$ value & 0.75 & 0.55 & 0.45 & 0.37 \\
\hline
\end{tabular}

${ }^{\mathrm{z}}$ Black and clear plastic mulch both years was 25.4 $\mu \mathrm{m}$ (Climagro, Delhi, ON, Canada). fruit weight due to year, harvest date, or mulch $(P \geq 0.24)$ (Table 4$)$, nor were there any interactions (Table 3 ). In contrast, grafting treatment affected total fruit number and weight in both years $(P<0.0001$ and $P=0.002$, respectively) (Table 5). The average total number of fruit per plant over all three harvest dates was 2.1 and ranged from 0.7 (nongrafted 'Secretariat') to 3.7 ('Secretariat' grafted onto 'Super Shintosa' and 'Tetsukabuto'). The average total fruit weight over all three harvest dates was $9.4 \mathrm{~kg}$ per plant and ranged from $3.2 \mathrm{~kg}$ (nongrafted 'Secretariat'), to $5.3 \mathrm{~kg}$ ('Secretariat' grafted onto 'Round'), to $14.8 \mathrm{~kg}$ ('Secretariat' grafted onto 'Super Shintosa').

For fruit quality characteristics measured, no differences were found for year except for lycopene, and there were no interactions among treatment, harvest date, and year (Table 3). Although lycopene content differed by year $(P<0.0001)$, there were no differences due to harvest date $(P=0.48$ and $P=0.70$, respectively $)$, mulch $(P=0.92$ and $P=0.41$, respectively), or grafting treatment ( $P=0.99$ and $P=0.39$, respectively) either year. The overall mean lycopene content in 2018 was $52.44 \mu \mathrm{g} \cdot \mathrm{g}^{-1}$ and was $32.51 \mu \mathrm{g} \cdot \mathrm{g}^{-1}$ in 2019 (Table 6), a 38\% difference. Hollow heart occurred on all harvest dates with no differences due to mulch $(P=0.42)$ or grafting treatment $(P=0.33)$. Overall average hollow heart rating was 3.2 (range 13$25 \mathrm{~mm}$ cracking) $(P=0.82)$ (Table 6$)$. The number of hard seeds due to harvest date $(P=$ $0.53)$, mulch $(P=0.61)$, and grafting treatment $(P=0.23)$ was not different, with an overall average number of six hard seeds per fruit (Table 6). Watermelon fruit firmness did

Table 5. Average fruit number and weight (kilograms) per plant and fruit firmness (Newton, N) of watermelon cv. Secretariat nongrafted and grafted onto four rootstock cvs. Tetsukabuto, Super Shintosa, Pelop, and Round at Mount Vernon, WA, in 2018 and 2019 (years combined).

\begin{tabular}{lccc}
\hline Treatment $^{\mathrm{z}}$ & Number of fruit & Fruit wt $(\mathrm{kg})$ & Fruit firmness $(\mathrm{N})$ \\
\hline Secretariat (control) & $0.7 \mathrm{~b}^{\mathrm{y}}$ & $3.2 \mathrm{c}$ & $4.3 \mathrm{c}$ \\
S/Tetsukabuto & $3.7 \mathrm{a}$ & $13.1 \mathrm{ab}$ & $6.1 \mathrm{ab}$ \\
S/Super Shintosa & $3.7 \mathrm{a}$ & $14.8 \mathrm{a}$ & $6.7 \mathrm{a}$ \\
S/Pelop & $1.2 \mathrm{~b}$ & $10.6 \mathrm{~b}$ & $5.7 \mathrm{~b}$ \\
S/Round & $1.3 \mathrm{~b}$ & $5.3 \mathrm{c}$ & $5.2 \mathrm{~b}$ \\
$P$ value & $<0.0001$ & 0.002 & $<0.0001$ \\
\hline
\end{tabular}

${ }^{\mathrm{z}}$ All grafted plants had watermelon cv. Secretariat $(\mathrm{S})$ as the scion and are denoted as scion-rootstock.

${ }^{\mathrm{y}}$ Means with the same letter within a column are not significantly different at $P<0.05$; means were discriminated using Tukey's honestly significant difference.

Table 6. Mean lycopene $\left(\mu \mathrm{g} \cdot \mathrm{g}^{-1}\right)$, hollow heart rating, hard seed count, fruit firmness (Newton, $\left.\mathrm{N}\right)$, and total soluble solids (TSS, \%) per watermelon fruit at three harvest dates, 0 , 7, and $14 \mathrm{~d}$ after physiological maturity (both the leaflet and tendril attached to the fruit pedicel were completely dry) at Mount Vernon, WA, in 2018 and 2019 (years combined).

\begin{tabular}{|c|c|c|c|c|c|c|}
\hline \multirow[b]{2}{*}{ Harvest } & \multicolumn{2}{|c|}{ Lycopene $\left(\mu \mathrm{g} \cdot \mathrm{g}^{-1}\right)$} & \multirow{2}{*}{$\begin{array}{l}\text { Hollow heart } \\
\qquad(1-5)^{\mathrm{y}}\end{array}$} & \multirow{2}{*}{$\begin{array}{c}\text { Number of } \\
\text { hard seed }\end{array}$} & \multirow{2}{*}{$\begin{array}{c}\text { Fruit } \\
\text { firmness }(\mathrm{N})\end{array}$} & \multirow[b]{2}{*}{ TSS $(\%)$} \\
\hline & $2018^{z}$ & 2019 & & & & \\
\hline$\overline{0 d}$ & 51.70 & 33.10 & 4.0 & 6 & 6.2 & 11.30 \\
\hline $7 \mathrm{~d}$ & 52.50 & 31.80 & 2.8 & 4 & 7.0 & 10.98 \\
\hline $14 \mathrm{~d}$ & 53.13 & 32.63 & 3.0 & 8 & 6.8 & 11.22 \\
\hline$P$ value & 0.49 & 0.70 & 0.82 & 0.45 & 0.07 & 0.09 \\
\hline
\end{tabular}

${ }_{\mathrm{z}}$ Lycopene analysis method in 2018 was (Davis et al., 2003) and in 2019 was modified from Nagata and Yamashita (1992).

${ }^{\mathrm{y}}$ Hollow heart rating on a 0 to 5 scale, where $0=$ no visible cracking; $1=<6 \mathrm{~mm}$ cracking in one direction, marketable; $2=6$ to $13 \mathrm{~mm}$ cracking in a single or multiple directions, marketable; $3=13$ to $25 \mathrm{~mm}$ cracking in one or multiple directions, not marketable; $4=25$ to $38 \mathrm{~mm}$ cracking in multiple directions, not marketable; and $5=>38 \mathrm{~mm}$ cracking with center cavity of fruit exposed, not marketable. not differ due to harvest date $(P=0.07)$ or mulch treatment $(P=0.45)$ but was different due to grafting treatment $(P<0.0001)$ in both years. Watermelon grafted onto 'Super Shintosa' rootstock had the firmest flesh $(6.7 \mathrm{~N})$ and nongrafted watermelon had the lowest firmness $(4.3 \mathrm{~N})$, while the other treatments were intermediate $(5.7 \mathrm{~N}$ on average) (Table 5). TSS was similar both years (11.2\% on average) and did not differ due to harvest date $(P=0.09)$, mulch $(P=0.32)$, or grafting treatment $(P=0.08)$ (Table 6$)$.

\section{Discussion and Conclusions}

In this study, the severity of verticillium wilt was unaffected by use of black or clear plastic mulch. These results differ from those of Dabirian et al. (2017), who used the same field and found that plants grown with black plastic mulch had AUDPC values $\approx 2$ times greater for verticillium wilt than plants grown with clear plastic mulch. In both studies, the average soil temperature under black plastic mulch $\left(25^{\circ} \mathrm{C}\right)$ was 3 to $5^{\circ} \mathrm{C}$ lower than under clear plastic mulch (28 to $\left.30{ }^{\circ} \mathrm{C}\right)$. This differences in disease severity among studies could be due to differences in $V$. dahliae soil populations in each study. For example, at the time of planting, $V$. dahliae soil populations was 5 to $15 \mathrm{cfu} / \mathrm{g}$ in the current study and was $28 \mathrm{cfu} / \mathrm{g}$ in the study by Dabirian et al. (2017). Other studies also reported that verticillium wilt and fusarium wilt (caused by Fusarium oxysporum) on cucumber (Cucumis sativus), tomato (Solanum lycopersicum), and strawberry (Fragaria ananassa) can be successfully managed by using clear plastic mulch (Ashworth and Gaona, 1982).

Verticillium wilt severity was 3.5 times less on grafted than on nongrafted 'Secretariat' plants, and rootstocks 'Super Shintosa', 'Tetsukabuto', 'Pelop', and 'Round' were equally effective in this study (227 AUDPC value on average). These results are similar to previous studies at the same experimental site where different watermelon scion cultivars (Crisp n Sweet, Sugar Baby, and TriX Palomar) grafted with different rootstocks cultivars (Emphasis, Just, Strongtosa, Super Shintosa, Tetsukabuto) also exhibited less disease than nongrafted watermelon plants (Buller et al., 2013; Dabirian et al., 2017; Wimer et al., 2015). Similarly, in Thessaloniki, Greece, Paroussi et al. (2007) reported that 'Crimson Sweet' grafted on 'Mamouth', 'Dako', and 'Calago' plants inoculated with $10^{6} \mathrm{~V}$. dahliae conidia per milliliter had infection of $20 \%$ to $37 \%$ compared with $87 \%$ infection for nongrafted plants. In contrast, Attavar et al. (2020) found no difference in disease severity between nongrafted 'Secretariat' and 'Secretariat' grafted onto 'Tetsukabuto' and 14 cucurbit germplasm accessions when $V$. dahliae population was $7.8 \mathrm{cfu} / \mathrm{g}$ soil and plants were inoculated with 104 cfu of $V$. dahliae microsclerotia at transplanting. Although it is not possible to directly compare inoculum levels between the two studies, the colony-forming unit count may underestimate the number of viable 
conidia by $50 \%$ (Jaronski and Liebmann, 2000).

Grafting 'Secretariat' onto 'Round' (bottle gourd) tended to delay female flowering by $7 \mathrm{~d}$ compared with nongrafted plants, and the delay was 11 to $14 \mathrm{~d}$ compared with grafting with 'Tetsukabuto' (interspecific hybrid squash). A similar result for interspecific hybrid squash rootstock was reported by Yamasaki et al. (1994). In contrast, Sakata et al. (2007) found earlier female flowering occurred when watermelon was grafted to bottle gourd rootstock. The differences in flower initiation response could be due to hormonal signaling combined with environmental affects that occur during graft union formation. For example, cytokinin is higher in grafted plants than nongrafted plants and could potentially have an effect on flowering time (Aloni et al., 2010; Kyriacou et al., 2017).

In the current study fruit from all treatments reached physiological maturity (senescence of leaflet and tendril attached to the fruit pedicel) at the same time in both years. A similar result was found in a study in Hermiston, OR, where first flowering was delayed $2 \mathrm{~d}$ for 'Secretariat' grafted with 'Shintosa Camelforce' and 'Tetsukabuto', but fruit reached physiological maturity at the same time as nongrafted plants (Devi et al., 2020). Although Attavar et al. (2020) reported that grafted treatments tended to flower at the same time as nongrafted 'Secretariat', a comparison of days to first harvest could not be made due to premature death of nongrafted plants from verticillium wilt. For nonclimacteric fruit like watermelon, fruit maturity at harvest has a major impact on fruit quality characteristics (Kader, 2008; Kyriacou et al., 2017). Reliable external indicators of fruit physiological maturity are needed to harvest fruit when quality is optimal, and further studies are needed to determine whether these external indicators apply to fruit of nongrafted as well as grafted plants. Further studies are also needed to assess more watermelon and rootstock cultivar combinations in a diversity of environments to test the reliability of these external maturity indicators.

Grafting can increase watermelon yield due to soilborne-disease resistance (Davis et al., 2008; King et al., 2008; Kyriacou et al., 2017). In the current study, a 3.4-fold increase in fruit weight per plant was achieved using grafted plants (Table 1) when $V$. dahliae soil population was 5 to $15 \mathrm{cfu} / \mathrm{g}$ at the time of planting. Dabirian et al. (2017) found a 1.8 -fold increase in fruit weight per plant when $V$. dahliae soil population was 28 $\mathrm{cfu} / \mathrm{g}$ at the time of planting and scionrootstock combinations were 'TriX Palomar' grafted with 'Super Shintosa', 'Tetsukabuto', and 'Just'. Similarly, Wimer et al. (2015) reported a 2.2-fold increase in fruit weight per plant when $V$. dahliae population was $18.0 \mathrm{cfu} / \mathrm{g}$ soil of at the time of planting and 'Sugar Baby' was grafted with 'Tetsukabuto'. Further, Paroussi et al. (2007) reported that yield of 'Crimson Sweet' grafted to
'Mamouth' rootstock had a 2.9-fold increase in weight per plant following plant inoculation with $10^{6}$ conidia of $V$. dahliae per milliliter. In contrast, at field sites in eastern Washington where the $V$. dahliae soil population density was low ( 1 to $5 \mathrm{cfu} / \mathrm{g}$ at the time of planting), fruit yield was similar for grafted and nongrafted treatments (Dabirian et al., 2017; Wimer et al., 2015). Although the threshold for watermelon is not known, these results indicate that grafting can increase watermelon productivity when $V$. dahliae soil population is above $5 \mathrm{~V}$. dahliae $\mathrm{cfu} / \mathrm{g}$ of soil.

Quality of grafted fruit must be equal to or better than that of nongrafted watermelon to ensure market acceptability (Bruton et al., 2009; Colla et al., 2010; Proietti et al., 2008). Although some studies have found grafting to have a negative impact on TSS and lycopene (Alexopoulos et al., 2007; Davis et al., 2008; Lee and Oda, 2003; López-Galarza et al., 2004), the current study did not show any differences between grafted and nongrafted watermelon fruit. Difference in lycopene content due to year in this study was likely due to the two methods that were used for the analysis each year. The potential cause may be the grinding of the sample in 2018, which results in small particles that aid lycopene extraction. Flesh firmness in the current study was greater for grafted 'Secretariat' than for the nongrafted treatment, as has been reported in numerous studies with other watermelon scions (Bruton et al., 2009; Buller et al., 2013; Dabirian et al., 2017; Davis and Perkins-Veazie, 2005; Devi et al., 2020; Kyriacou and Soteriou, 2015; Wimer et al., 2015; Yetisir et al., 2003). Increased flesh firmness in grafted watermelon could be due to higher cell density (Fallik and Ziv, 2020; Soteriou et al., 2017) and is a positive enhancement of fruit quality because firm fruit have an extended shelf life (Bruton et al., 2009; Saftner et al., 2006). However, in the current study, the overall hollow heart formation was high (13-25 mm cracking) for all treatments in both years, which is considered unmarketable. Although there is no definitive cause of hollow heart formation, studies suggest that multiple factors such as watermelon genetics, pollination/pollen viability, flowering time, and environmental stress such as cold night temperature can cause this physiological disorder, especially in seedless watermelon in the United States (Guan, 2018; Johnson, 2014, 2015). At the study site, night temperature was $10.5^{\circ} \mathrm{C}$ on average, which could account for the high incidence of hollow heart.

In conclusion, plastic mulch type (black and clear) did not have an impact on verticillium wilt severity when $V$. dahliae soil population was 5 to $15 \mathrm{cfu} / \mathrm{g}$, nor was there an effect on fruit yield or quality. Grafting did decrease disease severity and increase fruit yield compared with the nongrafted treatment under this $V$. dahliae soil population density, and $5 V$. dahliae cfu/g of soil may be the minimum level for impact on watermelon fruit yield. Further research is needed to better understand the yield potential of watermelon under different $V$. dahliae soil populations under different climatic conditions. Grafting increased fruit firmness but did not alter other fruit quality attributes. However, fruit maturity indices are needed to compare results across studies that have different scion and rootstock cultivar combinations and varying environmental conditions. Consistent with other studies, grafted watermelon has the potential to increase watermelon yield in the United States when there is disease pressure from $V$. dahliae.

\section{Literature Cited}

AgWeatherNet. 2020. The Washington agricultural weather network. 4 Feb. 2020. <https:// weather.wsu.edu/>.

Alan, O., N. Zdemir, and Y. Nen. 2007. Effect of grafting on watermelon plant growth, yield and quality. J. Agron. 6:362-365.

Alan, O., F. Sen, and E. Duzyaman. 2018. The effectiveness of growth cycles on improving fruit quality for grafted watermelon combinations. Food Sci. Technol. 38:270-277.

Alexopoulos, A.A., A. Kondylis, and H.C. Passam. 2007. Fruit yield and quality of watermelon in relation to grafting. J. Food, Agr. Environ. 5:178-179.

Aloni, B., R. Cohen, L. Karni, H. Aktas, and M. Edelstein. 2010. Hormonal signaling in rootstock-scion interactions. Scientia Hort. 127:119-126.

Ashworth, L.J., Jr. and S.A. Gaona. 1982. Evaluation of clear polyethylene mulch for controlling verticillium wilt in established pistachio nut groves. Phytopathology 72:243-246. 12 Feb. 2018. <https://www.apsnet.org/publications/ phytopathology/backissues/Documents/1982Articles/ Phyto72n02_243.PDF>.

Attavar, A., L. Tymon, P. Perkins-Veazie, and C. Miles. 2020. Cucurbitaceae germplasm resistance to verticillium wilt and grafting compatibility with watermelon. HortScience 55 : 141-148.

Baker, J.T., D.R. Earhart, M.L. Baker, F.J. Dainello, and V.A. Haby. 1998. Interactions of poultry litter, polyethylene mulch and floating row covers on triploid watermelon. HortScience 33:810-813.

Berlanger, I. and M.L. Powelson. 2000. Verticillium wilt. The Plant Health Instructor. 22 Sept 2018. <http://www.apsnet.org/edcenter/intropp/ lessons/fungi/ascomycetes/Pages/VerticilliumWilt. asp $>$.

Bhat, R.G. and K.V. Subbarao. 1999. Host range specificity in Verticillium dahliae. Phytopathology 89:1218-1225.

Brown, J.E. and C. Channell-Butcher. 1999. Effects of row cover and black plastic mulch on yield of 'AU Producer' watermelon on hilled and flat rows. J. Veg. Crop Prod. 5:67-71.

Bruton, B.D., W.W. Fish, K.V. Subbarao, and T. Isakeit. 2007. First report of verticillium wilt of watermelon in the Texas high plains. Plant Dis. 91:1053.

Bruton, B.D., W.W. Fish, W. Roberts, and T.W Popham. 2009. The influence of rootstock selection on fruit quality attributes of watermelon. Open Food Sci. J. 3:15-34

Buller, S., D. Inglis, and C. Miles. 2013. Plant growth, fruit yield and quality, and tolerance to verticillium wilt of grafted watermelon and tomato in field production in the Pacific Northwest. HortScience 48:1003-1009. 
Butterfield, E.J. and J.E. DeVay. 1977. Reassessment of soil assays for Verticillium dahliae. Phytopathology 67:1073-1078.

Candir, E., H. Yetişir, F. Karaca, and D. Ustun. 2013. Phytochemical characteristics of grafted watermelon on different bottle gourds (Lagenaria siceraria) collected from the Mediterranean region of Turkey. Turk. J. Agr. For. 37:443-456.

Colla, G., C.M.C. Suarez, M. Cardarelli, and Y. Rouphael. 2010. Improving nitrogen use efficiency in melon by grafting. HortScience 45:559-565.

Dabirian, S., D. Inglis, and C. Miles. 2017. Grafting watermelon and using plastic mulch to control verticillium wilt caused by Verticillium dahliae in Washington. HortScience 52:349-356.

Davis, A.R. and P. Perkins-Veazie. 2005. Rootstock effects on plant vigor and watermelon fruit quality. Cucurbit Genet. Coop. Rpt. 28-29:3941. 27 July 2019. <http://cuke.hort.ncsu.edu/cgc/ cgc2829/cgc2829-11.pdf>.

Davis, A.R., P. Perkins-Veazie, Y. Sakata, S. López- Galarza, J.V. Maroto, S.G. Lee, Y.C. Huh, A. Miguel, S.R. King, R. Cohen, and Y.M. Lee. 2008. Cucurbit grafting. Crit. Rev. Plant Sci. 27:50-74.

Davis, A.R., W.W. Fish, and P. Perkins-Veazie. 2003. A rapid hexanefree method for analyzing lycopene content in watermelon. J. Food Sci. 68:328-332.

Devi, P., S. Lukas, and C. Miles. 2020. Fruit maturity and quality of splice-grafted and one-cotyledon grafted watermelon. HortScience 55:1090-1098.

Fallik, E. and C. Ziv. 2020. How rootstock/scion combinations affect watermelon fruit quality after harvest? J. Sci. Food Agr. 100:32753282.

Flores, F.B., P. Sanchez-Bel, M.T. Estan, M.M. Martinez-Rodriguez, E. Moyano, B. Morales, J.F. Campos, J.O. Garcia-Abellán, M.I. Egea, N. Fernández-Garcia, and F. Romojaro. 2010. The effectiveness of grafting to improve tomato fruit quality. Scientia Hort. 125:211-217.

Fradin, E.F. and B.P. Thomma. 2006. Physiology and molecular aspects of verticillium wilt diseases caused by $V$. dahliae and V. albo-atrum. Mol. Plant Pathol. 7:71-86.

Ghimire, S., A.L. Wszelaki, J.C. Moore, D.A. Inglis, and C. Miles. 2018. The use of biodegradable mulches in pie pumpkin crop production in two diverse climates. HortScience 53:288-294.

Ghimire, S., E. Scheenstra, and C.A. Miles. 2020. Soil-biodegradable mulches for growth, yield, and quality of sweet corn in a Mediterraneantype climate. HortScience 55:317-325.

Georgia Vegetable Team. 2000. Commercial watermelon production. Univ. Ga. Coop. Ext. Serv. Bul. 996.V. 22 Mar. 2018. <https://secure.caes.uga.edu/ extension/publications/files/pdf/B\%20996_4.PDF>.

Goud, J.C. and A.J. Termorshuizen. 2003. Quality of methods to quantify microsclerotia of Verticillium dahliae in soil. Eur. J. Plant Pathol. 109:523-534.

Goud, J.C., A.J. Termorshuizen, and W. Gams. 2003. Morphology of Verticillium dahliae and $V$. tricorpus on semi-selective media used for the detection of $V$. dahliae in soil. Mycol. Res. 107:822-830.

Guan, W. 2018. Hollowheart of watermelons. Pu. Univ. Coop. Ext. Serv. Veg. Crops Hotline. 10 Dec. 2019. <https://vegcropshotline.org/article/hollowheart-of-watermelons/>.

Ibarra-Jimenez, L., J. Munguia-Lopez, A.J. Lozanodel Rio, and A. Zerrmeno-Gonzalez. 2005. Effect of plastic mulch and row covers on photosynthesis and yield of watermelon. Aust. J. Exp. Agr. 45:1653-1657.

Jaronski, S. and J. Liebmann. 2000. Direct spore counts vs. colony forming unit counts as methods for quantifying viable Beauveria bassiana conidia. Proc. Annu. Mtg. Soc. Invertebrate Pathol. 2000. 13 June 2018. <https://www.ars.usda.gov/research/ publications/publication/?seqNo115 $=130900>$.

Johnson, G. 2014. These beautiful watermelon patterns are driving everyone crazy. 22 Aug. 2018. <https://www.boredpanda.com/weirdwatermelons-beautiful-hollow-heart/>.

Johnson, G. 2015. Research finds potential cause of hollow heart disorder in watermelon. 22 Aug. 2018. <https://phys.org/news/2015-06-potential-hollow-heart-disorder-watermelons.html $>$.

Kader, A.A. 2008. Flavor quality of fruits and vegetables. J. Sci. Food Agr. 88:1863-1868.

Karaca, F., H. Yetişir, I. Solmaz, E. Çandır, S. Kurt, N. Sari, and Z. Guler. 2012. Rootstock potential of Turkish Lagenaria siceraria germplasm for watermelon: Plant growth, yield and quality. Turk. J. Agr. For. 36:167-177.

King, S.R., A.R. Davis, W. Liu, and A. Levi. 2008. Grafting for disease resistance. HortScience 43:1673-1676.

Kyriacou, M. and G. Soteriou. 2015. Quality and postharvest performance of watermelon fruit in response to grafting on interspecific cucurbit rootstocks. J. Food Qual. 38:21-29.

Kyriacou, M.C., Y. Rouphael, G. Colla, R. Zrenner, and D. Schwarz. 2017. Vegetable grafting: The implications of a growing agronomic imperative for vegetable fruit quality and nutritive value. Front. Plant Sci. 8:741.

Lee, J.M. 1994. Cultivation of grafted vegetables I. current status, grafting methods, and benefits. HortScience 29:235-239.

Lee, J.M. and M. Oda. 2003. Grafting of herbaceous vegetable and ornamental crops. Hort. Rev. 28:61-123.

López-Galarza, S., A. San Batista, D.M. Perez, A. Miquel, C. Baixauli, B. Pascual, J.V. Maroto, and J.L. Guardiola. 2004. Effects of grafting and cytokinin-induced fruit setting on colour and sugar-content traits in glasshouse-grown triploid watermelon. J. Hort. Sci. Biotechnol. 79:971-976.

Miguel, A., J.V. Maroto, A. San Bautista, C. Baixauli, V. Cebolla, B. Pascual, S. LópezGalarza, and J.L. Guardiola. 2004. The grafting of triploid watermelon is an advantageous alternative to oil fumigation. Scientia Hort. 103:9-17.

Miles, C., L. Hesnault, S. Johnson, P. Kreider, and S. Dabirian. 2016. Vegetable grafting: Watermelon. Washington State Univ. Ext. Pub. FS100E. 20 Mar. 2018. <https://s3.wp.wsu.edu/ uploads/sites/2071/2014/04/Grafting-WatermelonFS100E.pdf $>$.

Nagata, M. and I. Yamashita. 1992. Simple method for simultaneous determination of chlorophyll and carotenoids in tomato fruit. J. Jpn. Soc. Food Sci. Tech. 39:925-928.

Paplomatas, E.J., K. Elena, and A. Tsagkarakou. 2000. Screening tomato and cucurbit rootstocks for resistance to Verticillium dahliae. EPPO Bul. 30:239-242.

Parmar, H.N., N.D. Polara, and R.R. Viradiya. 2013. Effect of mulching material on growth, yield and quality of watermelon (Citrullus Lanatus Thunb) cv. Kiran. Univers. J. Agr. Res. 1:30-37.

Paroussi, G., F. Bletsos, G.A. Bardas, J.A. Kouvelos, and A. Klonari. 2007. Control of fusarium and verticillium wilt of watermelon by grafting and its effect on fruit yield and quality. Proc. IIIrd
Balkan Symp. Veg. and Potatoes. Acta Hort. (ISHS) 729:281-285.

Peel, M.C., B.L. Finlayson, and T.A. McMahon. 2007. Updated world map of the KöppenGeiger climate classification. Hydrol. Earth Syst. Sci. 11:1633-1644.

Proietti, S., Y. Rouphael, G. Colla, M. Cardarelli, M. De Agazio, M. Zacchini, E. Rea, S. Moscatello, and A. Battistelli. 2008. Fruit quality of mini-watermelon as affected by grafting and irrigation regimens. J. Sci. Food Agr. 88:1107-1114.

Pscheidt, J.W. and C.M. Ocamb. 2019. Watermelon (Citrullus spp.) verticillium wilt. PNW Dis. Mgt. Hdbk. Oregon State Univ. 7 Aug. 2019. <https://pnwhandbooks.org/plantdisease/ host-disease/watermelon-citrullus-spverticilliumwilt>.

Pulgar, G., G. Villorar, D.A. Morenu, and L. Romero. 2000. Improving the mineral nutrition in grafted watermelon plants: Nitrogen metabolism. Biol. Plant. 43:607-609. 3 Aug. 2018. $<$ https://link.springer.com/content/pdf/10.1023/ A:1002856117053.pdf>.

Rouphael, Y., D. Schwarz, A. Krumbein, and G. Colla. 2010. Impact of grafting on product quality of fruit vegetables. Scientia Hort. 127:172-179.

Rao, K.V.R., A. Bajpai, S. Gangwar, L. Chourasia, and K. Soni. 2017. Effect of mulching on growth, yield and economics of watermelon (Citrullus lanatus Thunb). Environ. Ecol. 35:2437-2441. 10 Sept. 2019. <https://www.researchgate.net/profile/Arpna_Bajpai/publication/ 315012260_Effect_of_Mulching_on_Growth_ Yield_and_Economics_of_Watermelon_Citrullus_ lanatus_Thunb/links/58c830ff45851591df3457fb/ Effect-of-Mulching-on-Growth-Yield-and-Economics-of-Watermelon-Citrullus-lanatus-Thunb. pdf $>$.

Saftner, R., J.A. Abbott, G. Lester, and B. Vinyard. 2006. Sensory and analytical comparison of orange-fleshed honeydew to cantaloupe and green-fleshed honeydew for fresh-cut chunks. Postharvest Biol. Technol. 42:150-160.

Sakata, Y., T. Ohara, and M. Sugiyama. 2007. The history and present state of the grafting of cucurbitaceous vegetables in Japan. Acta Hort. 731:159-170.

Satoh, S. 1996. Inhibition of flowering of cucumber grafted on rooted squash stocks. Physiol. Plant. 97:440-444.

Shaner, G. and R.E. Finney. 1977. The effect of nitrogen fertilization on the expression of slow mildewing resistance in Knox wheat. Phytopathology 67:1051-1056.

Sintim, H.Y., S. Bandopadhyay, M.E. English, A.I. Bary, J.M. DeBruync, S.M. Schaeffer, C.A. Miles, J.P. Reganold, and M. Flury. 2019. Impacts of biodegradable plastic mulches on soil health. Agr. Ecosyst. Environ. 273:36-49.

Soteriou, G.A. and M.C. Kyriacou. 2014. Rootstock mediated effects on watermelon field performance and fruit quality characteristics. Intl. J. Veg. Sci. 21:344-362.

Soteriou, G.A., A.S. Siomos, D. Gerasopoulos, Y. Rouphael, S. Georhiadou, and M.C. Kyriacou. 2017. Biochemical and histological contrition to texture changes in watermelon fruit modulated by grafting. Food Chem. 237: $133-140$.

U.S. Department of Agriculture. 2019. Web soil survey. 10 Oct. 2019. <https://websoilsurvey.sc.egov.usda.gov/ App/HomePage.htm>.

Vallad, G.E. and K.V. Subbarao. 2008. Colonization of resistant and susceptible lettuce cultivars by a green fluorescent protein-tagged 
isolate of Verticillium dahliae. Phytopathology 98:871-885.

Wimer, J.A., C.A. Miles, and D.A. Inglis. 2015. Evaluating grafted watermelon for verticillium wilt severity, yield, and fruit quality in Washington State. HortScience 50:1332-1337.

Yamasaki, A., M. Yamashita, and S. Furuya. 1994. Mineral concentrations and cytokinin activity in the xylem exudate of grafted watermelons as affected by rootstocks and crop load. J. Jpn. Soc. Hort. Sci. 62:817826.

Yetisir, H., N. Sari, and S. Yucel. 2003. Rootstock resistance to fusarium wilt and effect on watermelon fruit yield and quality. Phytoparasitica 31:163-169.
Yetisir, H. and N. Sari. 2003. Effect of different rootstock on plant growth, yield and quality of watermelon. Austral. J. Expt. Agr. 43:12691274.

Zhang, H., L. DeVetter, E. Scheenstra, and C. Miles. 2020. Weed pressure, yield, and adhesion of soil-biodegradable mulches with pumpkin. HortScience 55:1014-1021. 